\title{
A Study on Cost of Cultivation and Production of Turmeric in Erode District of Tamil Nadu
}

\author{
T. Saravanan' ${ }^{1}$ and L. Mothi ${ }^{2 *}$ \\ 'Assistant Professor, PG and Research Department of Economics, Chikkaiah Naicker College, Erode, Tamil Nadu, \\ India; saravanannkl79@gmail.com \\ ${ }^{2}$ Ph.D Research Scholar of Economics (F/T), Chikkaiah Naicker College, Erode, Tamil Nadu, India; \\ mothi.194@gmail.com
}

\begin{abstract}
India is basically an agrarian society and since time immemorial trading of agricultural produce began for exchange of money. Turmeric being a tropical plant native to India, many states are engaged in its cultivation. However, the study was conducted to find out the cost of cultivating turmeric and the returns reaped and the efficiency with which the input resources are utilized by the farmers in Erode district of Tamil Nadu. In fact, the study has exposed that the farmers have underutilized the input resources and hence it is suggested to the farmers of turmeric to aim at achieving optimum utilization of input resources to enhance their net returns.
\end{abstract}

Keywords: Cultivation, Farmer, Production Cost, Turmeric

\section{Introduction}

India is basically an agrarian society and since time immemorial trading of agricultural produce began for exchange of money. Turmeric being a tropical plant native to India, many states is engaged in its cultivation. However, the study was conducted to find out the cost of cultivating turmeric and the returns reaped and the efficiency with which the input resources are utilized by the farmers in Erode district of Tamil Nadu.

\section{Review of Literature}

Karthik and Amarnath ${ }^{1}$ revealed the cost of cultivation of turmeric and the net income per hectare. Applying the Cobb-Douglas production function, the study also exposed that planting material, nitrogen, potash, harvesting and curing; machine hours and irrigation contributed significant influence on the yield of turmeric. However, the non-availability of labor and pest and disease attack were the major constraints in production.

Murugananthi, Shivakumar and Aijan² in their paper examined the relationship between turmeric futures price traded in National Commodity and Derivatives Exchange (NCDEX), Mumbai and spot price prevailed in Erode market over a period of eight years (2004-2012) to show the presence of unidirectional causality from futures price to spot price and the occurrence of price transmission from futures market to spot prices of turmeric.

Reji and Edakkandi Meethal ${ }^{3}$ concluded that an increasing demand for the organic turmeric products from both domestic as well as international markets offers scope for further growth and development of small scale organic turmeric processing enterprises in Odisha. However, the present study is undertaken to probe the costs and returns of turmeric cultivation, resource use efficiency on turmeric farms along with the marketing aspects, in Erode district.

\section{Objectives of the Study}

- To workout the costs and returns in the cultivation of turmeric.

- To assess the input resource utilization to achieve efficiency.

*Author for correspondence 


\section{Data Source and Methodology}

This study is largely based on primary data. Primary data was collected from the growers practicing modern farming system and organic farming system in the select areas of Erode, Kodumudi and Modakurichi taluks of Erode district of Tamil Nadu, focusing on the cost of cultivation of turmeric. Another schedule was prepared to collect data from the select conventional farmers about their cost of cultivation.

Required secondary data was collected from the Government website of the Directorate of Economics and Statistics and the Season and Crop Report of Government of Tamil Nadu. The farmers who are engaged in the cultivation of turmeric in a minimum of one acre of land to a maximum of even more than five acres of land are in all the select areas of Erode District. Convenience sampling method was adopted in the final sample size of 90 respondents. Out of 90 respondents in Erode district, 27 farmers were marginal land holders, 31 were small farmers and 32 were large farmers.

\section{Tools of Analysis}

In order to understand the study on cost of cultivation and marketing of turmeric in Erode district of Tamil Nadu, the cost of cultivation was calculated on per hectare basis separately for all the three groups of farmers. Further, the efficiency of the input resource utilization was assessed through MVP/MIC ratio.

\section{Analysis and Discussion}

From Table 1 it could be observed that the total cost of production varied considerably, and it was lower for large farmers. The total cost of production per hectare was Rs. 202,220 for marginal farmers, Rs. 173,883 for small farmers and Rs. 161,644 for large farmers. Cost of production per $\mathrm{kg}$ disclosed in Table 2 also showed a decline as the size of the farms increased. It was Rs. 26.81, Rs. 22.49 and Rs. 19.64 respectively for the marginal, small and large farmers.

This is probably due to increase in the efficiency in use of resources in large farms together with economies of scale of production. Gross returns per hectare were the highest for large farmers (Rs. 301,600) when compared to small (Rs. 309,200) and marginal (Rs. 329,200) farmers. The net returns per hectare also showed an increase as the size of the farms increased. It was Rs. 99,380, Rs. 135,317 and Rs. 167,556 respectively in case of marginal, small and large farmers. The net return per hectare was the highest for large farmers because the cost of production per hectare was less for large farms when compared to small and marginal farms. The gross return obtained by the large farmers was also high. This can be inferred to arise from economies of scale of production in large farms.

Table 1. Cost of Cultivation of Turmeric of Sample Farmers (Cost of Cultivation in Rs./ha)

\begin{tabular}{|c|c|c|c|c|c|}
\hline S.No. & Cost components & $\begin{array}{c}\text { Marginal } \\
(\mathbf{n}=27)\end{array}$ & $\begin{array}{l}\text { Small } \\
(n=31)\end{array}$ & $\begin{array}{c}\text { Large } \\
(\mathrm{n}=32)\end{array}$ & Overall \\
\hline 1. & Labor & $\begin{array}{r}84955 \\
(42.01) \\
\end{array}$ & $\begin{array}{r}80910 \\
(46.53) \\
\end{array}$ & $\begin{array}{r}73123 \\
(45.24) \\
\end{array}$ & $\begin{array}{r}79354 \\
(44.57) \\
\end{array}$ \\
\hline 2. & Cost of rhizomes & $\begin{array}{r}24785 \\
(12.26) \\
\end{array}$ & $\begin{array}{r}24785 \\
(14.25) \\
\end{array}$ & $\begin{array}{r}24785 \\
(15.33) \\
\end{array}$ & $\begin{array}{r}24785 \\
(13.92) \\
\end{array}$ \\
\hline 3. & Transportation charge & $\begin{array}{r}7214 \\
(3.57) \\
\end{array}$ & $\begin{array}{r}7214 \\
(4.15) \\
\end{array}$ & $\begin{array}{r}7214 \\
(4.46) \\
\end{array}$ & $\begin{array}{r}7214 \\
(4.05)\end{array}$ \\
\hline 4. & Organic manure & $\begin{array}{r}29785 \\
(14.73) \\
\end{array}$ & $\begin{array}{r}19785 \\
(11.38) \\
\end{array}$ & $\begin{array}{l}14785 \\
(9.15)\end{array}$ & $\begin{array}{r}21007 \\
(11.80) \\
\end{array}$ \\
\hline 5. & $\begin{array}{l}\text { Fertilizers and plant protection } \\
\text { chemicals }\end{array}$ & $\begin{array}{r}20214 \\
(10.00) \\
\end{array}$ & $\begin{array}{l}15214 \\
(8.75)\end{array}$ & $\begin{array}{r}24214 \\
(14.98) \\
\end{array}$ & $\begin{array}{r}19914 \\
(11.19) \\
\end{array}$ \\
\hline 6. & Herbicide & $\begin{array}{r}5321 \\
(2.63)\end{array}$ & $\begin{array}{r}2821 \\
(1.62)\end{array}$ & $\begin{array}{r}1821 \\
(1.13)\end{array}$ & $\begin{array}{r}3215 \\
(1.81)\end{array}$ \\
\hline 7. & Interest on working capital & $\begin{array}{l}19236 \\
(9.51)\end{array}$ & $\begin{array}{l}16716 \\
(9.61)\end{array}$ & $\begin{array}{l}14497 \\
(9.82)\end{array}$ & $\begin{array}{l}16683 \\
(9.37)\end{array}$ \\
\hline 8. & $\begin{array}{l}\text { Depreciation + Interest on fixed } \\
\text { capital + Land revenue }\end{array}$ & $\begin{array}{l}10705 \\
(5.29)\end{array}$ & $\begin{array}{r}6433 \\
(3.70)\end{array}$ & $\begin{array}{r}1201 \\
(0.74)\end{array}$ & $\begin{array}{r}5854 \\
(3.29)\end{array}$ \\
\hline & Total variable cost & 191510 & 167445 & 160439 & 172172 \\
\hline
\end{tabular}




\begin{tabular}{|l|l|c|c|c|c|}
\hline S.No. & \multicolumn{1}{|c|}{ Cost components } & $\begin{array}{c}\text { Marginal } \\
(\mathbf{n = 2 7})\end{array}$ & $\begin{array}{c}\text { Small } \\
(\mathbf{n = 3 1 )}\end{array}$ & $\begin{array}{c}\text { Large } \\
(\mathbf{n}=\mathbf{3 2})\end{array}$ \\
\hline & Total fixed cost & 88955 & 45121 & 9812 & 47962 \\
\hline & Total cost & 202220 & 173882 & 161643 & 178026 \\
& & $(100.00)$ & $(100.00)$ & $(100.00)$ & $(100.00)$ \\
\hline
\end{tabular}

Source: Primary data

Figures in paranthesis are percentage to the total cost.

Table 2. Summary of Output and Returns (Cost and Returns in Rs./ha)

\begin{tabular}{|c|l|r|r|r|}
\hline S.No. & \multicolumn{1}{|c|}{ Output and returns } & Marginal & Small & Large \\
\hline 1. & Total cost of production & 202220 & 173883 & 161644 \\
\hline 2. & Average production quintal/ha & 75.4 & 77.3 & 82.3 \\
\hline 3. & Gross returns @ Rs 4000/quintal & 301600 & 309200 & 329200 \\
\hline 4. & Net returns & 99380 & 135317 & 167556 \\
\hline 5. & Cost of production/kg & 26.81 & 22.49 & 19.64 \\
\hline 6. & Net returns/kg & 13.18 & 17.51 & 20.35 \\
\hline
\end{tabular}

Source: Primary data

Table 3. MVP/MIC Ratio for Input Used

\begin{tabular}{|c|c|c|c|c|c|}
\hline S.No. & Input & *MPP & $* \mathrm{MVP}$ & $* \mathrm{MIC}$ & $\begin{array}{c}\text { MVP/MIC } \\
\text { Ratio }\end{array}$ \\
\hline 1. & Quantity of rhizome & 0.012972 & 51.88847 & 10 & 5.18 \\
\hline 2. & Labor & 0.055553 & 222.2136 & 105 & 2.11 \\
\hline 3. & Quantity of organic manure & 0.000373 & 1.492767 & 1 & 1.49 \\
\hline 4. & Quantity of inorganic fertilizers & 0.008346 & 33.38547 & 5 & 6.67 \\
\hline \multicolumn{2}{|r|}{ Source: Primary data } & $\begin{array}{l}\text { *MPP - Marginal } \\
\text { Profit of Production. }\end{array}$ & $\begin{array}{l}\text { *MVP - Marginal } \\
\text { Value Product. }\end{array}$ & $\begin{array}{l}\text { Margina } \\
\text { ost. }\end{array}$ & \\
\hline
\end{tabular}

It could be seen from Table 3 that MVP/MIC ratio was greater than one for input of rhizome, labor, quantity of organic manure and quantity of inorganic fertilizer which therefore indicates the under utilization of these input resources by the sample farmers in cultivating turmeric.

\section{Conclusion}

The study was purposively conducted to assess the cost of cultivating turmeric among all the marginal, small and large farmers to achieve profitable returns for their hard work and also assess the utilization level of the input resources to encourage them to continue their agricultural operations. It is found that the input resources were all underutilized as the MVP/MIC ratio was more than one for all inputs. However, the cost of production per kg of turmeric was on a decline to small and large farmers when compared to marginal farmers, while the net returns per kg of turmeric was on an increase to small and large farmers when compared to marginal farmers. Hence, it is concluded that all farmers of turmeric in the study area must aim at achieving optimal utilization of input resources to enhance their net returns further.

\section{References}

1. Karthik V, Amarnath JS. An economic analysis of turmeric production in Tamil Nadu, India. Direct Research Journal of Agriculture Food and Science, 2014; 2(6):66-76.

2. Murugananthi D, Shivakumar KM, Aijan N. Price discovery of Indian turmeric in futures market. International Journal of Commerce and Business Management. 2013; 6(2):166-170.

3. Meethal RE. A study on value chains for integrating small producers into market: Small-scale organic turmeric processing enterprises in Odisha. IUP Journal of Business Strategy. 2013; 10(2):38-49. 